\title{
Militares pardos e pretos e sua "utilidade" para o bom governo da região de Serro Frio: notas de pesquisa*
}

\author{
Browns and blacks in the military and their "usefulness" \\ for the good government of the Serro Frio region: \\ research notes \\ Negros y pardos militares y su "utilidad" \\ para el bueno gobierno de la región de Serro Frio: \\ notas de investigación
}

Ana Paula Pereira Costa**

Resumo: Neste texto analisa-se a experiência da mobilização de tropas de pardos e de pretos em variados serviços de manutenção da ordem pública em um território que teve sua origem ligada às atividades de exploração do ouro e de pedras preciosas e que, portanto, foi marcado por um contexto de tensões e constantes mudanças econômicas, políticas, sociais e territoriais, a saber: a comarca de Serro Frio, entre os anos de 1730 a 1763. Objetiva-se assinalar a importância e a utilidade que a mobilização das tropas de pardos e pretos tinha na visão das autoridades locais para ordenar este território mineiro, sobretudo no que concerne aos excessos e inconveniências causadas por fugas de escravos, roubos, garimpo ilegal, sendo a atuação dessas tropas colocadas como imprescindíveis ao bom funcionamento da governabilidade da região.

Palavras-chave: tropas de pardos e de pretos; serviço militar; Serro Frio

\footnotetext{
* Este trabalho apresenta alguns resultados do projeto Negros escravos, forros e livres na estrutura militar lusitana: um estudo sobre a atuação de 'Milícias particulares' de escravos e das tropas Milicianas e de Ordenanças de negros. Serro Frio, século XVIII apoiado pelo programa institucional de iniciação científica e tecnológica - PIBIC/CNPq. Agradeço a ajuda dos bolsistas do projeto, Janaína Ladeira Venâncio e Joelmir Cabral Moreira, bem como a ajuda dos bolsistas voluntários: Kelly Sellani, Rosilene Santos Aparecida e Eduardo Jonas Caldeira.

**Doutora em História Social pela Universidade Federal do Rio de Janeiro (UFRJ). <anappcosta@, ig.com.br $><$ dados biográficos/biographic data $>$
} 


\begin{abstract}
This paper analyzes the experience of mobilizing the browns' and blacks' troops in varying maintenance of public order services in a territory that had its origin linked to gems and gold exploration activities and that, therefore, was marked by a context of tensions and constant economic, political, social and territorial changes, namely: the region of Serro Frio, between the years 1730-1763. The objective is to point out the importance and usefulness that the mobilization the browns' and blacks' troops had in the point of view of the local authorities to order this territory, especially in regard to the excesses and inconveniences caused by the scape of slaves, theft, illegal mining, being the actions of these troops placed as essentials to the proper functioning of the governance of the region.
\end{abstract}

Keywords: troops of browns and blacks; military service; Serro Frio

Resumen: Este trabajo analiza la experiencia de la movilización de las tropas de negros y pardos para la manutención del orden público en un territorio que ha tenido su nacimiento enlazado a la actividad de exploración de oro y piedras preciosas y, por lo tanto, se caracterizó por un contexto de tensiones y cambios económicos, políticos, sociales y territoriales, es decir, la región de Serro Frio, entre los años 1730 a 1763. El objetivo es señalar la importancia y utilidad que las tropas pardas y negras han tenido para las autoridades locales colocaren orden en este territorio, especialmente en relación a los excesos y las molestias causados por la fuga de esclavos, el robo y minería ilegal, siendo las acciones de las tropas tomadas como esencial para el buen funcionamiento de la gobernabilidad de la región.

Palabras clave: negros y pardos militares; servicio militar; Serro Frio

As ações e manifestações envolvendo militares nos vastos espaços da América portuguesa durante o período colonial vêm sendo objeto de estudos em uma perspectiva renovada. Uma questão oriunda desse debate, e que se articula com o revisionismo perpetrado desde os anos de 1980 em torno da análise da sociedade colonial brasileira e da escravidão africana nesse território, se refere à presença de homens pretos e pardos no universo bélico do Império lusitano. O presente trabalho objetiva analisar a importância e o caráter de utilidade que a mobilização das tropas de pardos e de pretos tinha na visão das autoridades locais (governadores, intendentes, ouvidores, capitães-mores, contratadores) para ordenar um território que teve sua origem ligada às atividades de exploração do ouro e de pedras preciosas e que, portanto, foi marcado por um contexto de tensões e constantes mudanças econômicas, políticas, sociais e territoriais, a saber: a comarca de Serro Frio entre os anos de 1730 a 1763 . Objetivamos assinalar a mobilização dessas forças em atividades ligadas aos excessos e inconveniências causadas por fugas de escravos e quilombolas, roubos, extravios, garimpo ilegal, sendo a atuação dessas tropas colocadas como imprescindíveis ao bom funcionamento da governabilidade da região. 
$\mathrm{O}$ recorte inicial abarca o momento imediatamente posterior ao anúncio oficial de descoberta de diamantes na localidade, fato que gerou grandes preocupações para a Coroa lusitana no que diz respeito à forma como administrar a extração e a fiscalização das pedras preciosas, bem como gerou grandes mudanças para a ocupação e a organização dessa paragem. O marco final justifica-se por ser a data que marca o fim do governo de Gomes Freire de Andrada na capitania de Minas Gerais. Em 1733 Gomes Freire foi nomeado para governar a capitania do Rio de Janeiro. Dois anos depois, passava a administrar também a região de Minas Gerais, cuidando, assim, do principal eixo econômico da América portuguesa naquele momento, em decorrência da descoberta de metais preciosos. Logo teve desafios importantes a enfrentar, como a implementação do então novo sistema de arrecadação de imposto sobre o ouro, a capitação. Para tanto, Gomes Freire passou a viajar, a partir de 1735, todos os anos para as Minas - o que ocorreu até 1752 - percorrendo diversas regiões mineiras, dentre as quais se incluía Serro Frio. Além do novo método de cobranças de impostos, tornava-se premente também uma maior fiscalização e controle daquela área, visando organizar a produção aurífera, conter o contrabando (RIBEIRO, 2011, p. 83) e, acrescentamos, lidar com os constantes problemas causados pelas fugas de escravos e crimes por eles cometidos no território. Desta maneira, buscamos entender a atuação e mobilização das tropas de pardos e de pretos nesse contexto que fez parte da região dos diamantes, no qual as bases de sua organização e governabilidade foram sendo delineadas de forma processual a fim de lidar com os problemas colocados.

\section{Negros e pardos no universo militar colonial: história e historiografia}

Em um artigo publicado em 2003, a historiadora Sílvia Lara chamou a atenção para a existência de dois movimentos historiográficos revisionistas surgidos no Brasil quase simultaneamente - a partir da década de 1980 - que, apesar de tratarem de temas complementares (o estudo da escravidão africana e seus descendentes no Brasil e a análise da sociedade colonial), permaneceram restritos a seus eixos específicos (LARA, 2005, p. 33).

$\mathrm{O}$ primeiro conjunto historiográfico questionou, sobretudo, o enfoque estritamente macroeconômico e a ênfase no caráter violento e inexorável da escravidão a fim de romper com estudos que se apoiassem em uma ótica senhorial que era, inevitavelmente, excludente. Novas 
pesquisas passaram a valorizar a experiência escrava analisando os valores e as ações dos mesmos como elementos importantes para a compreensão da própria escravidão e de suas transformações. Já o segundo movimento repensou a natureza das conexões metrópole/colônia, refutando a ideia de que suas relações se pautariam em dualidades e contradições de interesses meramente econômicos. Um foco maior sobre a política foi realizado e a partir de um diálogo com uma historiografia notadamente portuguesa, que revitalizou a ótica da sociedade de Antigo Regime, novas abordagens sobre as relações de poder no mundo colonial surgiram. Pesquisas sobre os modos de governar e sobre o funcionamento de diversas instituições, que agregavam e davam consistência às redes hierárquicas que ligavam horizontal e verticalmente a sociedade colonial, foram se desenvolvendo em conexão com estudos realizados para outras partes do Império português (África e Ásia) (LARA, 2005, p. 31-35).

De lá para cá, alguns historiadores brasileiros têm procurado conectar essas historiografias, conforme sugestão de Sílvia Lara, num esforço para complexificar e sofisticar as análises desses dois campos. A própria autora reconheceu que, já naquele momento de alerta, alguns trabalhos se desenvolviam nessa direção procurando responder muitas questões em aberto. Entretanto, observava que era preciso mais:

A aproximação entre os estudiosos da escravidão e do período colonial não é apenas uma questão de passar a estudar o tema numa outra cronologia ou de incluir mais um item na pauta de questões acerca da vida nas conquistas. Se os estudos dos modos de governar só têm a ganhar se passarem a incorporar em suas reflexões as ações e valores daqueles que aparentemente eram excluídos das redes de poder, também as pesquisas sobre escravidão serão beneficiadas se voltarem a olhar mais cuidadosamente para o comportamento dos senhores e das autoridades coloniais (LARA, 2005, p. 37-38).

Ou seja, para se conectar historiografias é preciso indagar sobre o modo como a escravidão e o Antigo Regime estiveram intrinsicamente ligados e conviveram na América portuguesa (LARA, 2005, p. 38). Nesse debate que vem se articulando, três pontos que têm sido cada vez mais referenciados por fazerem parte da preocupação dos historiadores são: a presença estrutural da população negra no mundo colonial brasileiro, inserida mediante a escravidão africana, os mecanismos da dominação escravista e o surgimento de um grande contingente de libertos e livres nesta colônia, oriundos da escravidão, alforria e mestiçagem (LARA, 2004, p. 16-17; cf. também FRAGOSO, BICALHO \& GOUVÊA, 2001, 
FURTADO, 2001 e ALENCASTRO, 2000). Desta forma, a presença estrutural dos escravos, libertos e livres na América portuguesa, ainda que analisada de formas e a partir de formulações conceituais diversas, tem sido apontada como o diferencial mais importante pelos autores que, desde então, lidaram com o tema. No entanto, se o centro dos questionamentos continua a ser a presença massiva desses grupos e o modo como se tornaram um elemento estrutural na colônia, trata-se também, em segundo lugar, de entender como podiam estar integrados à rede hierárquica que ordenava as relações sociais nas conquistas ultramarinas. As teses sobre a rigidez das relações sociais na colônia e as que afirmavam a incompatibilidade entre as estruturas do Antigo Regime e a presença da escravidão e dos pardos e pretos (escravos ou não) já não se sustentam diante dos conhecimentos acumulados nos últimos anos sobre a sociedade e a política coloniais (LARA, 2004, p. 17).

Neste sentido, novas investigações têm procurado analisar como a escravidão e os homens e mulheres oriundas e descendentes dessa dinâmica foram incorporados à teia hierárquica que ordenava a sociedade colonial brasileira e codificava as relações sociais no Antigo Regime (LARA, 2004, p. 18), permeada pelos valores de honra, prestígio, distinção, desigualdade e hierarquização. Dentre os mecanismos de hierarquização e alcance de distinções sociais para a parcela negra da população que existia na América portuguesa durante o período colonial, há muito se vem destacando a importância da esfera militar.

$\mathrm{Na}$ América lusitana, havia diferentes formas de incorporar os pardos e os pretos escravizados, forros ou livres no âmbito militar. Tais homens podiam, por exemplo, ser utilizados de uma forma privada, como uma espécie de guarda pessoal constituída informalmente, isto é, sem a conotação militar que se associava às tropas de pardos e de pretos montadas recorrentemente durante todo o período colonial em caso de necessidade, sendo a mais famosa conhecida como Terço dos Henriques. Para o caso de Minas Gerais, os inúmeros relatos dos indivíduos que se aventuraram nas trilhas dos sertões mineiros em busca de títulos, sesmarias, patentes e cargos políticos, no intuito de conseguir poder ou prestígio e, assim, tornarem-se potentados locais, denotam bem esta situação. Em tais relatos, deixavam claro que viam nas conquistas a serem realizadas, feitas à custa de suas vidas, fazendas e negros armados, oportunidades para adquirirem riqueza, poder e status (cf. COSTA, 2010).

Com efeito, acompanhados de seus negros armados (nesses casos quase sempre escravos), muitos potentados das Minas, sobretudo em 
seus anos iniciais de formação, atuaram sistematicamente em combate a levantes e conflitos, internos e externos, em povoamento de novos territórios, a fim de angariar mercês e reconhecimento social. Mais do que a participação dos colonos na conquista do território colonial, afirmações como estas devem explicitar a importância dos escravos para os seus senhores. A relevância destas ligações com os escravos se evidenciava não só porque na sociedade colonial o escravismo articulava as relações sociais, mas porque, em muitos casos, esses cativos forneciam segurança aos potentados ao atuarem como uma pequena milícia para protegê-los nas rixas e conflitos em que se envolviam (KARASCH, 2000 , p. 260). Além disso, podiam ser usados nos serviços de El-Rei como braço armado, possibilitando a aquisição de mercês régias.

Além do uso dos negros escravizados como milícia particular, outra maneira pela qual se associava os pardos e os pretos (escravos, livres e libertos) ao âmbito bélico era através de seu atrelamento a estrutura formal da organização militar lusitana, sendo essa forma de arregimentação que buscamos analisar no presente texto. Classicamente, a estrutura militar formal lusitana tem sido apresentada a partir de três tipos de forças, que estabeleciam um padrão válido para toda a colônia luso-americana: os corpos regulares, conhecidos também por tropa paga ou de linha, as milícias ou corpos de auxiliares e as ordenanças ou corpos irregulares (COSTA, 2006, p. 17; ver também COTTA, 2005 e JESUS, 2012, p. 314). Entretanto, conforme assinalou Nauk Maria de Jesus citando Francis Cotta, a análise do âmbito militar colonial a partir desse clássico tripé faz perder de vista as especificidades locais. Dentre os vários argumentos que Cotta elaborou para ratificar tal tese destaca-se, por exemplo, o fato de capitanias como a do Rio de Janeiro, São Paulo e Bahia se preocuparem em edificar fortalezas e adestrar seus contingentes para um provável confronto que viria do mar. Já as demais capitanias se preocupavam com a defesa das fronteiras terrestres - que iam do Mato Grosso ao Amapá (COTTA, 2004, p. 218, apud JESUS, 2012, p. 314-315).

Em trabalho anterior ressaltamos que as poucas análises sobre a história militar para o contexto colonial gerou a falta de uma visão de um universo bélico de Antigo Regime socialmente complexo (COSTA, 2006, p. 53). Sobre essa questão em particular, recentemente alguns trabalhos sob os auspícios da chamada Nova História Militar ${ }^{1}$ têm

${ }^{1}$ Para esclarecimentos sobre essa definição ver (HESPANHA, 2003), (CASTRO, IZECKSOHN e KRAAY, 2004), (MOREIRA e LOUREIRO, 2012). 
procurado matizar tal lacuna, embora ainda haja muito a ser feito. Uma relevante contribuição dessa nova historiografia tem sido a atenção dada para o estudo de outras formas de tropas militares mais específicas que subdividiam as forças de acordo com as hierarquias sociais (indígenas, pretos, pardos e brancos) $)^{2}$. Assim, os pardos e os pretos podiam ser agrupados, basicamente, em quatro espécies de milícias: as companhias auxiliares de infantaria, as companhias de ordenanças de pé, os corpos de pedestres e os corpos de homens do mato (COTTA, 2005, p. 201).

Luís Geraldo Silva, ao abordar o período da invasão holandesa no nordeste açucareiro (1630-1654), ressalta que nesse momento foram criadas as milícias de pardos e de pretos na América portuguesa. Reconquistados Pernambuco e as demais capitanias do Norte em 1654, em boa medida graças aos esforços dos colonos brancos e dos pardos, dos pretos e dos índios a eles subalternos, os chamados terços de homens de cor, foram ali mantidos e depois, ao longo dos séculos XVII e XVIII, se disseminaram por praticamente todas as capitanias da colônia brasileira (SILVA, 2012, p. 71). Ainda sobre essa situação e contexto, Hebe Mattos destaca que não são poucas as referências que revelam os ganhos dos soldados das companhias em luta em Pernambuco (inclusive os das tropas de pardos e de pretos) com os escravos capturados do inimigo pelas tropas portuguesas que, via de regra, eram vendidos para a Bahia e seu valor repartido entre os soldados como recompensa (MATTOS, 2006, p. 34).

Analisando a formação das tropas de pretos na sociedade Pernambucana dos séculos XVI e XVIII, Kalina Vanderlei Silva chega mesmo a assinalar que, socialmente, a milícia se tornou, juntamente com as irmandades, o principal meio de ascensão social para negros livres e forros nesta localidade e um meio de distinção para escravos (SILVA, 2002, p. 2-3).

Por fim, temos o estudo de Francis Albert Cotta que analisou as trajetórias de militares negros e pardos patenteados, libertos e livres, que conseguiram alcançar relativa mobilidade social através de sua atuação e inserção no universo militar das Minas setecentista. Para este autor, a posse de uma patente militar dava aos negros, mestiços e pardos lugares de destaque na sociedade mineira do século XVIII, pois propiciava a esses homens considerável poder ao comandarem grandes contingentes de soldados e por lhes fornecer oportunidades de aderir

${ }^{2}$ Por exemplo (SILVA, 2002; COTTA, 2010; SILVA, 2012; MARTA, 2013; SILVA, 2013; PAULA, 2012). 
aos valores tidos como ideais pela sociedade católica portuguesa tais como o casamento, a formação de uma família e a posse de escravos (COTTA, 2010, p. 108-112).

Os estudos mencionados destacam a presença e a importância dos pardos e dos pretos no universo bélico, ressaltando a origem dessa mobilização, as situações em que se fizeram primordiais para a Coroa portuguesa e fornecem exemplos de ganhos que eles podiam adquirir ao se atrelarem à esfera militar. Para aprofundarmos essa discussão, no item a seguir, analisaremos a experiência da arregimentação desses homens em variados serviços de manutenção da ordem pública na região da comarca de Serro Frio, entre os anos de 1730 a 1763. Sua dinâmica de formação envolveu um processo acelerado e desordenado, o risco, a migração intensa de pessoas - livres e escravas -, a necessidade de controle do espaço, do contrabando e de vigilância dos caminhos. Contudo, se diferenciava de outros locais da capitania mineira pela presença dos diamantes e por ter um sistema de administração e de extração peculiar que foi se delineando ao longo do setecentos.

\section{Combatendo os quilombos, o contrabando e o extravio: a utilidade das tropas de pardos e de pretos para 0 "bom governo" da comarca de Serro Frio}

A região da comarca de Serro Frio, composta pelos termos de Vila do Príncipe e do Arraial do Tejuco, teve sua origem ligada às atividades de exploração do ouro e de pedras preciosas. Nos primórdios do século XVIII, foi descoberto ouro nas cabeceiras do Rio Jequitinhonha e seus afluentes. Por conseguinte, grandes levas de pessoas se dirigiram para o local, formando povoados. Dentre esses, temos o surgimento daqueles que depois ficaram conhecidos como Vila do Príncipe (atual cidade do Serro) e Arraial do Tejuco (atual cidade de Diamantina). Em 1729, foi anunciada a descoberta de diamantes nas rochas e no leito dos rios da região do Vale do Jequitinhonha. O comunicado chegou a Portugal em 1729, expedido pelo governador da capitania, D. Lourenço de Almeida. Com o anúncio oficial da descoberta, a Coroa tratou de pôr ordem na casa: organizou a exploração dos diamantes e a cobrança dos respectivos impostos. Entre 1729 a 1734, a exploração foi aberta a todos que tivessem escravos e capital para investir na mineração, mas cobrava-se uma taxa sobre cada escravo empregado nos trabalhos de extração. $\mathrm{O}$ aumento da produção trouxe rápida prosperidade à população da localidade, notadamente ao Arraial do Tejuco que crescia 
vertiginosamente (FURTADO, 2007, p. 308; ver também FURTADO, 1996 e 2003; SANTOS, 1976).

Divulgadas as riquezas das duas localidades citadas, ambas tornaramse o centro de convergência de exploradores e comerciantes, atraídos pelo ouro e, sobretudo, pelos diamantes. Para elas deslocaram-se principalmente paulistas, portugueses e negros, ao lado de outros estrangeiros em número menor. Entretanto, o avanço territorial e demográfico da ocupação dessa região de Minas Gerais se fez acompanhar por um aumento correspondente das tensões econômicas, sociais e políticas. Sua ocupação correspondia, com enorme rapidez, à formação de grandes fortunas e de uma desordem perigosa, regulada a balas de chumbo. Nessa dinâmica, era crucial para a Coroa buscar a fiscalização de gentes e de impostos, vigiar e policiar o imbricado complexo de caminhos e trilhas (RESENDE, 2007, p. 29). Assim, na localidade, foram tomadas algumas medidas visando esse fim. Em 1734, foi estabelecida a Demarcação Diamantina, também chamada de Distrito Diamantino. Tratava-se inicialmente de um quadrilátero em torno do Arraial do Tejuco, que foi designado sede tanto do Distrito quanto da Intendência dos Diamantes. Incluía outros arraiais e povoados como Gouveia, Milho Verde, São Gonçalo, Chapada, Rio Manso, Picada e Pé do Morro, e poderia ter seu contorno alterado para englobar outras locais onde fossem realizadas novas descobertas. Administrativamente, a região continuou dependente da Câmara e da Ouvidoria da Vila do Príncipe, sede da comarca de Serro Frio. Com a Demarcação, ficou proibida a exploração de diamantes na área e, consequentemente, a chegada de novos exploradores, até que o preço da pedra preciosa, que caiu vertiginosamente devido ao excesso de oferta no mercado mundial, se normalizasse. Só em 1739 a exploração foi reaberta, mas sob um novo sistema, o de contrato, aparentemente mais fácil de ser controlado. A partir de 1745, visando aumentar o controle sobre o território e dificultar o afluxo de pessoas não ligadas diretamente à exploração diamantina, a entrada na Demarcação passou a ser controlada, podendo ocorrer somente em locais determinados: os registros. Esses eram também uma espécie de alfândega, lugares de cobrança de direitos de entradas/impostos sobre escravos, gado, carga de secos e molhados. Em Serro Frio, concentravam-se em Caeté-Mirim, Rabello, Palheiro, Pé-do-Moro, Inhacica e Paraúna (FURTADO, 2007, p. 309-311). Para a vigilância das estradas, a fim de evitar a evasão fiscal, a entrada ilegal de pessoas na comarca e patrulhar os perigos dos caminhos, pois os viajantes eram constantemente atacados, instalaram-se, junto aos registros, as guardas ou destacamentos militares (RESENDE, 2007, p. 29-31). 
Além da preocupação de se ordenar a área mineradora, que era formada por povoados, vilas e freguesias, havia ainda, por parte do monarca e das autoridades régias, a preocupação em fiscalizar os sertões que ficavam em seu entorno, pois estes eram caracterizados como locais de revoltas, motins, refúgio de quilombolas, de bandidos, contrabandistas e gentio bravo (MORAES, 2007, p. 77). Dentre todos os perigos mencionados, interessa-nos refletir sobre aqueles relacionados aos problemas de perturbação da ordem e da tranquilidade pública implementados pela parcela negra da população, bem como aqueles relacionados aos frequentes problemas do extravio e contrabando, característicos de uma localidade mineradora. Para a região assinalada, era constante, na documentação administrativa, reclamações e preocupações acerca da presença de contrabandistas, de garimpeiros ilegais, das fugas de escravos, da formação de quilombos, de roubos e outros crimes por eles cometidos nas trilhas e veredas formadas e da necessidade de policiá-las. Para tanto, como demonstraremos mais adiante, autoridades como governadores, intendentes, ouvidores, capitães-mores, contratadores que passaram pela comarca de Serro Frio sugeriam, em suas correspondências enviadas ao Reino, o uso dos pardos e de pretos em serviços bélicos para coibir essas ameaças. Esses homens eram comumente agrupados, como já mencionado, em companhias de infantaria auxiliar de pardos e de pretos libertos, ordenanças de pé de pardos e de pretos libertos, corpos de pedestres e corpos de homens do mato e de assalto.

Os terços de infantaria auxiliar de pardos e pretos libertos eram forças militares comandadas pelo mestre-de-campo, cargo atribuído geralmente a um homem pardo. Ainda sobre a hierarquização dessa força militar, encontramos os sargentos-mores e seus ajudantes, que desempenhavam a função do treinamento e disciplina, seguidos pelos capitães, tenentes e alferes. As companhias auxiliares de infantaria de pretos e pardos libertos podiam atuar tanto na destruição de quilombos e repressão aos índios, quanto na defesa das fronteiras marítimas e terrestres (COTTA, 2010, p. 68-70).

Nas ordenanças de pé de pardos e pretos libertos, o comando era exercido por um oficial da tropa regular, o sargento-mor, seguido pelo posto de capitão-de-distrito e o de alferes, responsáveis pela disciplina e organização do corpo militar. Nas ordenanças de pé não existiam os postos de tenente, tenente-coronel e coronel. Outra característica da ordenança de pé era que, se composta por soldados e cabos negros, os seus oficiais seriam negros; no caso de serem pardos, seus capitães 
e alferes seriam pardos. Os integrantes das ordenanças não recebiam soldos, armamento ou equipamento para o desempenho das atividades bélicas. Nas companhias de ordenanças de pé de homens pardos e pretos libertos, as principais missões estavam relacionadas aos confrontos com os quilombolas e índios bravos. Atuavam, assim, localmente para preservar a tranquilidade e o sossego públicos (COTTA, 2010, p. 70-73).

$\mathrm{O}$ terceiro tipo de milícia era o corpo de pedestre. O comando dessa milícia era dado a homens pardos. Nas Minas Gerais, os pedestres existiam em maior número, segundo Francis Cotta, na Repartição Diamantina. Esse grupo era especializado em ações em locais de difícil acesso. Eles "entravam nos matos, descendo córregos por despenhadeiros impraticáveis" (COTTA, 2010, p. 74). Pela vasta experiência eram requisitados como guias nas expedições militares. Tinham seus soldos e jornais pagos pela Fazenda Real e eram comandados por capitães pardos. Na região de extração de diamantes os pedestres participavam de diligências relativas à prisão de escravos fugitivos, garimpeiros clandestinos e contrabandistas (COTTA, 2010, p. 74-80).

Por fim, os corpos de homens do mato eram compostos por pardos, negros libertos e escravos. A hierarquia dessa força se dividia em: capitão-mor do mato, sargento-mor do mato, capitão do mato, cabo do mato e soldado do mato. A legitimação dos postos de capitão do mato era realizada através da emissão de uma carta patente, que se iniciava com a indicação dos pretendentes ao posto pelos camaristas da região na qual ela seria exercida. Posteriormente, os documentos com as indicações dos camaristas eram repassados ao governador que emitia a patente com o nome do candidato escolhido e depois a enviava ao rei de Portugal para ser confirmada. Para os postos de cabos e soldados, a indicação era realizada pelos próprios oficiais dos corpos, não havendo necessidade de cartas patentes. Os locais de atuação dos capitães do mato eram as matas, rios, picadas e sertões. Eles não recebiam soldos, fardamentos, equipamentos, armamentos ou alimentação da Fazenda Real. Eram recompensados através das tomadias ${ }^{3}$ pagas pelos proprietários dos escravos fugidos (COTTA, 2010, p. 82-86).

Todas essas forças existiram nas Minas desde os primeiros anos do setecentos e foram vistas de maneiras distintas pelas diversas autoridades e pela população. Os documentos que serão listados a seguir expressam a importância e o caráter de utilidade que a mobilização

${ }^{3}$ Tomadia: quantia paga ao capitão-do-mato pelo proprietário de um escravo recapturado. (COTTA, 2010, p. 86). 
das tropas de pardos e de pretos tinha na visão das autoridades locais para ordenar este território mineiro, sobretudo no que concerne aos excessos e às inconveniências causadas por fugas de escravos e quilombolas, roubos, extravios, garimpo ilegal e outros crimes por eles cometidos na região de Serro Frio. Nos vários requerimentos e cartas do Arquivo Histórico Ultramarino consultadas para esta localidade, elaboradas por governadores, intendentes, ouvidores, capitães-mores, contratadores, etc., era recorrente o destaque dado para a experiência da arregimentação dos pardos e dos pretos em variados serviços de combate a tais inimigos internos, para a vigilância dos caminhos e para a perseguição do contrabando, sendo a atuação dessas tropas colocadas como imprescindíveis ao bom funcionamento da governabilidade da região.

O primeiro documento, datado de 1731, refere-se a uma carta que o ouvidor da comarca de Serro Frio, Antônio Ferreira do Vale de Melo, enviou a D. João V informando acerca dos excessos cometidos na referida comarca pelos negros quilombolas. Na correspondência, o ouvidor reconheceu a atuação crucial da figura do capitão do mato para resolver o problema dos ataques dos quilombolas, ao que parece, frequentes, nos caminhos que levavam ao Arraial do Tejuco e ressaltou que a população do lugar ficou tão satisfeita com os serviços prestados pelo referido militar, que solicitou que sua vigilância fosse constante a fim prevenir os ataques. Segundo a correspondência:

Este serro do frio teve no ano próximo passado em tal consternação com os negros fugidos a que chamam calhambolas que infestando todas as estradas e cometendo a cada ano mortes, roubos e outros excessos não havia quem se atravessasse a ir dos arraiais para fora e dentro destes se não davam os homens por seguros. E o caminho mais infestado foi o das Minas para esta vila por onde quando passei no mesmo ano para as Gerais foi me necessário trazer muita gente de acompanhamento por não experimentar alguma desatenção dos ditos negros e ao seguinte dia em que passei pela passagem chamada o Tijuco se fizeram nela cinco mortes entre estas a de um religioso de São Bento e nos outros dias seguintes muitas outras chegando o seu desaforo até a tirarem mulheres das casas de seus maridos e levarem nas para os matos, e a forma das mortes que davam as mais das pessoas que matavam era sangrando as por várias partes do corpo e deixando as esvair em sangue até expirarem e a uma delas crucificaram na. $\mathrm{O}$ que fazendo eu presente ao governador das Minas D. Lourenço de Almeida para que desse nisso o remédio e providência que lhe parecesse ordenou me que ajuntasse eu com 
um ou mais capitães do mato o que se lhe havia dar para serem soldados prontos e extinguirem os quilombos dos ditos negros e que para pagamento deste estipêndio tomasse aquilo que fosse bastante por cada cabeça de escravo (...) em virtude da qual assim o fiz e ajustando com um capitão do mato homem de esforço e o melhor rastejador que tem nestas Minas e dando toda a ajuda necessária fez este com seus soldados nos ditos quilombos aonde se lhe puseram os negros em resistência uma tal mortandade que logo cessaram as ruínas que eles causavam, e ficou por hora esta comarca sossegada e o povo tão satisfeito do que obrou o dito capitão que geralmente me requerem que lhe podiam pagar todos os anos a porção que fosse justa para que continuasse no mesmo exercício e não sucedesse os mesmos negros a fazer semelhantes agravos e a engrossarem se de novos quilombos e com efeito assim o vou fazendo praticar $(. . .)^{4}$.

De acordo com Mariana Dantas, para lidar eficientemente com o problema de escravos fugidos, a criação e a manutenção de um regimento paramilitar de caçadores ou esquadras do mato foram as principais estratégias adotadas no período colonial brasileiro (DANTAS, 2006, p. 258). Os profissionais que compunham a tropa recebiam o nome genérico de capitães do mato. A participação nessa atividade profissional exigia certo conhecimento e preparo em função dos riscos do ofício (GUIMARÃES, 2007, p. 449). Encarregados de vigiar as localidades em que habitavam, capturar e retornar escravos fugidos, os capitães do mato também contavam com autoridade para recrutar soldados e formar esquadras utilizadas em campanhas contra quilombos. Estas esquadras eram organizadas nos mesmos moldes hierárquicos das forças militares coloniais e eram pagas por recompensas por escravo capturado, como sugere a fonte em destaque (DANTAS, 2006, p. 258-259).

Através da consulta feita no Arquivo Histórico Ultramarino em documentos referentes à comarca de Serro Frio, fica claro que as tropas de capitães do mato eram presença constante no dia a dia da região, cujo auxílio para resolver problemas com roubos, quilombolas, contrabando e até mineração ilegal feita por escravos, era solicitado pela população mais ampla, por membros da elite e por autoridades régias. Os relatos construídos por autoridades, como o do documento destacado acima, sugerem que a necessidade do uso dos pardos e pretos em variadas

\footnotetext{
${ }^{4}$ Arquivo Histórico Ultramarino (AHU), Minas Gerais, Cx. 19, Doc. 1. Grifo meu. Cabe assinalar que na transcrição dos documentos selecionados fizemos a atualização ortográfica, visando a facilitar o entendimento de algumas formas do português arcaico.
} 
situações como reforço bélico era algo corriqueiro e colocado como fundamental para lidar com problemas de desassossego público.

Mesma lógica constatamos nos dois documentos que serão analisados a seguir. Em setembro de 1745 os oficiais da Câmara de Vila do Príncipe escreveram uma carta ao rei D. João V e ao governador Gomes Freire expondo "o prejuízo que sentiam com a fuga e posterior confiscação dos escravos para as terras demarcadas dos diamantes", solicitando ordem régia para que "não se confiscassem os mesmos sem prova de que andavam minerando por consentimento de seus donos". $\mathrm{Na}$ carta, os camaristas esclareceram que o prejuízo era grande, já que eram muitos escravos que fugiam e que acabavam sendo encontrados pelos capitães do mato e confiscados pela Real Fazenda ao invés de ser devolvidos para seus senhores. De acordo com o relato:

É geral o prejuízo que recebem os moradores desta comarca na perda de seus escravos que por qualquer leve causa, ou sem ela, pela sua malevolência por se vingarem de seus senhores ou por quererem mudar de senhor para que sempre lhe perpende o gênio lhe fogem e se metem nos córregos dos diamantes e terras deles demarcadas de modo que sejam achados pelas patrulhas dos soldados e capitães do mato para que assim sejam confiscados conforme um bando que assim o determina muito observar por V. Majestade, sem mais averiguação ou prova de verdade que acharem se nas terras demarcadas com instrumentos de minerar minerando em locais em que hajam diamantes ou suspeita de que o possa haver, e para evitar um semelhante prejuízo recorremos a V. Majestade que se digne por no referido a providência necessária e se não confisquem os escravos sem prova de que andam minerando por mandado ou consentimento de seus senhores ${ }^{5}$.

Outro documento que revela a importância e auxílio das tropas de capitães do mato em situações problemáticas e que precisavam ser sanadas para o bom funcionamento da região analisada, datado de março de 1746, trata sobre o requerimento feito pelo contratador de diamantes, o sargento-mor João Fernandes de Oliveira. Nesta consulta, o Conselho Ultramarino revelou que o dito contratador solicitou a criação de mais algumas companhias de Dragões (a tropa paga de Minas Gerais) para as terras demarcadas, devido à falta de guarda que aí se verificava. No requerimento do contratador, o mesmo expôs a precariedade da guarnição do Distrito Diamantino feita pelos Dragões, o que dificultava

\footnotetext{
${ }^{5}$ AHU, Minas Gerais, Cx. 45, Doc. 80. Grifo meu.
} 
o combate ao contrabando, roubos, ataques de quilombolas, enfim, o policiamento e a fiscalização das terras demarcadas. Para remediar a situação, o contratador relatou que utilizou os serviços de soldados e capitães do mato, pagos por ele mesmo, e que havia também solicitado ao governador da capitania, Gomes Freire, que a Fazenda Real se dispusesse a pagar mais desses oficiais, no que não foi atendido por motivos expostos no requerimento:

João Fernandes de Oliveira rematante e administrador do contrato dos diamantes do serro do frio, fez petição a V. Majestade por este concelho em que diz que necessitando-se de muitas guardas para se evitar o roubo deles e se guardarem as terras demarcadas por serem de muitas léguas e de grandes embaraços não são bastantes os soldados Dragões que naquela diligência se ocupam ainda que sejam de cinquenta até sessenta porque precisamente há muitos impedidos com doenças e cobrança da capitação no sertão para onde saem (...) e sem bastarem os capitães do mato do contrato a quem o suplicante paga especialmente no tempo presente em que os mais dos roceiros e moradores daquele distrito se encaminharam para o novo descoberto do ouro do Paracatu, com o que ficou tudo despovoado e se tem cheio o terreno do quilombo de negros fugidos do mesmo contrato, e com tantos insultos de roubos e mortes e tal consternação, que os feitores e administradores do contrato além da grande vigilância em que estão temem a sua morte e do suplicante por haver constado várias vezes pretenderem levantar-se os ditos negros do contrato e matarem os brancos e porque pedindo o suplicante ao governador capitão general daquela capitania mais soldados ou capitães do mato a quem pague a real fazenda na forma das condições se lhe não dão pelos não haver, pois os soldados pagos da mesma capitania não chegam para as diligencias das intendências. Pede a V. Majestade lhe faça mercê atentando serem guardadas aquelas terras e da falta de soldados e capitão do mato mandar se criar mais alguns dos Dragões $(. . .)^{6}$.

Verifica-se pela fonte acima que a opção pela criação de mais algumas companhias de Dragões para as terras demarcadas a fim de contornar os problemas destacados pelo contratador foi pensada só depois que a alternativa de se usar soldados e capitães do mato se esgotou. Obviamente, havia uma hierarquia das tropas e a de Dragões se colocava em um patamar superior se comparada com as tropas de homens do mato, e que a criação das companhias pagas acarretava um

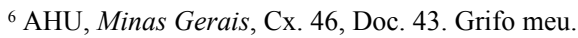


ônus para a Coroa, daí existirem em menor número e sua implementação exigir mais cuidado. Todavia, não nos interessa discutir tais questões com a análise do documento citado. $\mathrm{O}$ que buscamos enfatizar é o caráter da utilidade, a constante presença e a relevância que os serviços das tropas compostas por pardos e pretos foram adquirindo para a governabilidade e sossego de regiões coloniais como a de Serro Frio. Já na primeira metade do século XVIII, temos menção da existência desses tipos de forças na localidade em foco, sendo extremamente atuantes em questões variadas, reafirmando o argumento anteriormente colocado de que o clássico tripé das forças militares lusas não permite pensar as especificidades locais.

Cabe lembrar que, conforme apontaram recentemente alguns estudos, em Minas Gerais colonial essa questão do armamento da parcela negra da população e seus descendentes fomentou discussões, dúvidas e polêmicas quanto à medida certa de seu emprego (PAIVA, 2006; REIS, 2004). Assim, se o uso constante de tropas compostas por homens pardos e pretos denota que tal prática era algo corriqueiro para os habitantes da capitania mineira, toda uma legislação que defendia o uso moderado das armas indica que apesar de corriqueiro isso era algo que preocupava as autoridades coloniais. Não por acaso, tentativas de regulamentação do porte de armas não foram poucas visando, inclusive, pôr fim às tropas armadas. Entretanto, esse é um ponto ainda pouco trabalhado pela historiografia, sobretudo para a região abarcada pela presente pesquisa, haja vista que só muito recentemente, no âmbito da história militar e colonial, os pesquisadores passaram a se interessar em compreender o comportamento e as instituições militares em seus contextos social, político, econômico e cultural (MOREIRA; LOUREIRO, 2012, p. 16). De todo modo, o fato é que se tornou costume a política de utilização e recrutamento de homens pardos e pretos em caso de movimentação bélica na região e período enfocados pela pesquisa. E ainda que essas tropas fossem irregulares e causassem polêmicas, abundavam ordens régias e diretrizes para a organização e utilização das mesmas.

As tropas compostas por oficiais do mato não eram as únicas mobilizadas na comarca de Serro Frio para resolver contendas que atrapalhavam o sossego público e a governabilidade da região. No documento que será assinalado adiante, vemos a presença de outro tipo de tropa composta por pardos e por pretos, bem como por escravos armados, para lidar, mais uma vez, com problemas causados por quilombolas. Em janeiro de 1753, o governador interino das Minas, José Antônio Freire de Andrade, enviou a Diogo de Mendonça Corte-Real 
uma carta informando acerca dos roubos e outras violências cometidas pelos negros que andavam fugidos no Arraial do Tejuco. Para contornar a situação, o governador relatou as medidas tomadas para a manutenção da ordem, as quais envolviam a atuação de pardos e pretos. No caso desse relato, além da ajuda prestada pelas tropas de pedestres, bem como pela de Dragões, para combater as desordens, destaca-se também a atuação de escravos de um membro da elite local, o contratador Felisberto Caldeira Brant. Senão vejamos:

No dia nove de outubro do ano passado me chegou uma carta do comandante dos Dragões, que se acha destacado no serro frio, Simão da Cunha Pereira, nela me dava conta do desaforo em que se tinham posto os negros que andavam fugidos as casa de seus senhores com os mulatos, mestiços e carijós que se lhe tinham agregado roubando os córregos dos diamantes. Marchei no dia quinze deste continente trazendo comigo os poucos Dragões que restavam das patrulhas, que impedem a extração do ouro, logo que aqui cheguei reforcei a dos córregos sendo de pouca utilidade porque a poucos dias um lote de negros, mulatos e carijós me atacarão uma patrulha de dez soldados Dragões e dois pedestres. Sendo que os não podia prender ou afugentar da demarcação com as tropas pagas e que as ordenanças eram de má qualidade para andarem a pé nos córregos escrevi ao capitão Felisberto Caldeira Brant contratador dos diamantes (...) para que este mandasse por prontos dos homens que traz custeando o seu contrato cento e cinquenta e com este número e com os Dragões e pedestres em dia vinte de dezembro dando um assalto nos córregos se prenderão dezoito $(. . .)^{7}$.

Conforme já apontado, os pedestres eram uma força militar especializada em atuar em locais de difícil acesso. Eram mobilizados na região de extração de diamantes, como assinalou Francis Cotta, em diligências relativas à prisão de escravos fugitivos, garimpeiros clandestinos e contrabandistas, atuando diretamente com os Dragões, conforme mostra a correspondência acima. Na Demarcação Diamantina, ao longo do século XVIII, se distribuíam em destacamentos, nos registros e guardas (COTTA, 2010, p. 74-80). Em função do número reduzido de soldados e por questões estratégicas, os militares dos Dragões eram direcionados para locais nos quais se pagavam tributo (registros e passagens) e para regiões extratoras do ouro e diamante (COTTA, 2010, p. 81). Daí a importância e a presença de tropas como a dos pedestres, e

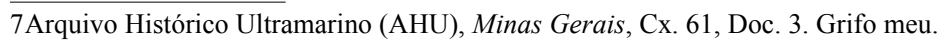


as do mato como visto anteriormente, em situações como as descritas em todos os documentos analisados no trabalho. Embora os Dragões, a tropa paga, se fizesse presente em algumas situações, as tropas compostas por pardos e por pretos, como evidenciado, prestavam valioso suporte no ataque a quilombolas, combate ao extravio e contrabando e a outros crimes.

Nos documentos selecionados, conseguimos perceber, no conjunto, a forma como autoridades entendiam a incorporação dos pardos e pretos na esfera militar, os tipos de serviços em que eram usualmente mais utilizados e os benefícios e ganhos que tal prática proporcionava para a Coroa lusa em sua governabilidade no além-mar, para os responsáveis pela administração local, bem como para os colonos em geral, já que graças a essas forças, o sossego da região podia ser efetuado.

\section{Considerações finais}

Percebe-se nas fontes citadas que a atuação de pardos e de pretos (cativos, forros ou livres) em serviços militares responsáveis por tarefas de grande perigo, tais como o controle dos descaminhos, a proteção contra ataques de criminosos e de escravos fugidos, era recorrente nas Minas. Conforme destacou Francis Cotta, a atribuição de entrar nos matos, em lugares intrincados e de difícil acesso acabou recaindo sobre os africanos e seus descendentes, cativos ou libertos, que passaram a integrar os terços de pardos e pretos libertos, as ordenanças de pé, os corpos de pedestres e os corpos de homens do mato e de assalto. Eles patrulhavam as estradas em busca de quilombolas, índios bravos, facinorosos e assaltantes que atacavam as vilas e arraiais. Eram os mais aptos a identificar rastros e vestígios de passagem de pessoas (COTTA, 2010, p. 65).

Para a comarca de Serro Frio, devido a sua importância para a Coroa portuguesa após a descoberta dos diamantes na primeira metade do século XVIII, e pela instabilidade social causada pelo grande afluxo populacional que para aí se dirigiu ao longo desse período em busca de riquezas, a constituição de um aparato militar, no qual muitos homens pardos e pretos foram utilizados, para controle da ordem interna se tornou imprescindível. A frequência com que tais homens foram empregados na manutenção da boa ordem da região pode ser apontada como mais um dos paradoxos que marcaram o relacionamento entre a sociedade colonial e sua população de origem e descendência africana. 
Duas possíveis explicações para esta prática seriam que, primeiro, havia uma escassez de homens brancos dispostos a cumprir esta função e, segundo, que era esta uma forma de cooptar libertos e seus descendentes, propiciando-lhes algum acesso ao poder (DANTAS, 2006, p. 263).

Desse modo, devido à intensa necessidade de manutenção da tranquilidade pública, de policiamento das terras diamantinas e devido à própria escassez de homens brancos para ocupar as fileiras das tropas, a população de pardos e pretos (escravos, forros e livres) teve de ser recrutada para os quadros desse universo bélico. Para esses indivíduos, autoridades e monarca essa situação era vantajosa, pois com essas forças formava-se um espaço de negociação entre os grupos pardos e pretos com o soberano e com governadores e demais autoridades que ofereciam aos primeiros uma moderada ascensão social em troca de uma parceria para lidar com os problemas de violência e falta de segurança pública.

Como bem ressaltou Mariana Dantas, "colocando o interesse da população em geral acima de suas próprias dúvidas, governos locais acabaram por aceitar uma aliança com parceiros que, em outras circunstâncias, seriam evitados" (DANTAS, 2006, p. 263).

Como se vê se, apesar dos riscos e preocupações, a necessidade colocada pelo contexto denota que as autoridades régias precisavam munir os homens pardos e pretos de facas, espadas e armas de fogo para que realizassem diversos tipos de trabalhos. Podemos sublinhar o imprescindível reforço e socorro que propiciavam às forças pertencentes à estrutura militar clássica para atuação na defesa e no ordenamento social e o auxílio que prestavam às autoridades metropolitanas para realização de serviços cruciais para o exercício da governabilidade régia em território ultramarino, conforme visto nos documentos mencionados. Ou seja, em várias situações, as autoridades régias permitiam e estimulavam os pardos e os pretos a usarem armas e a se atrelarem ao universo militar colonial, porque isso se fazia necessário em uma conjuntura em que a possibilidade de mobilizar homens para lutar era fator primordial para o sucesso das diligências de manutenção da ordem e, consequentemente, para a sustentação dos interesses régios no além-mar.

\section{Referências}

ALENCASTRO, Luiz Felipe de. O trato dos viventes. Formação do Brasil no Atlântico sul. Séculos XVI e XVII. São Paulo: Companhia das Letras, 2000.

BICALHO, Maria Fernanda. A cidade e o Império: o Rio de Janeiro no século XVIII. Rio de Janeiro: Civilização Brasileira, 2003. 
CASTRO, Celso; IZECKSOHN, Vitor; KRAAY, Hendrik (Org.). Nova história militar brasileira. Rio de Janeiro: FGV, 2004.

COSTA, Ana Paula Pereira. Atuação de poderes locais no Império Lusitano: uma análise do perfil das chefias militares dos Corpos de Ordenanças e de suas estratégias na construção de sua autoridade. Vila Rica (1735-1777). 2006. Dissertação (Mestrado em História) - Universidade Federal do Rio de Janeiro (UFRJ), Rio de Janeiro, 2006.

Armar escravos em Minas colonial: potentados locais e suas práticas de reprodução social na primeira metade do século XVIII. Vila Rica, 1711-1750. 2010. Tese (Doutorado em História) - Universidade Federal do Rio de Janeiro (UFRJ), Rio de Janeiro, 2010.

COTTA, Francis A. Organização militar. In: ROMEIRO, Adriana; BOTELHO, Ângela V (Orgs.). Dicionário histórico das Minas Gerais. Período colonial. Belo Horizonte: Autêntica, 2004. p. 218-223.

. No rastro dos Dragões: universo militar luso-brasileiro e as políticas de ordem nas Minas setecentistas. 2005. Tese (Doutorado em História) - Universidade Federal de Minas Gerais (UFMG), Belo Horizonte, 2005.

. Negros e mestiços nas milícias da América portuguesa. Belo Horizonte: Crisálida, 2010.

DANTAS, Mariana L. R. "Em benefício do bem comum”: esquadras de caçadores do mato nas Minas setecentistas. In: LIBBY, Douglas C.; FURTADO, Júnia F (Orgs.). Trabalho livre, trabalho escravo: Brasil e Europa, séculos XVII e XIX. São Paulo: Annablume, 2006. p. 251-272.

FRAGOSO, João. A nobreza vive em bandos: a economia política das melhores famílias da terra do Rio de Janeiro, século XVII: algumas notas de pesquisa. Revista Tempo, Niterói, v. 8, n. 15, p. 11-35, 2003.

FRAGOSO, João; BICALHO, Maria Fernanda; GOUVÊA, Maria de Fátima (Orgs.). O Antigo Regime nos trópicos: a dinâmica imperial portuguesa (séculos XVI-XVIII). Rio de Janeiro: Civilização Brasileira, 2001.

FURTADO, Júnia F. O livro da capa verde. São Paulo: Annablume, 1996.

. (Org.). Diálogos Oceânicos. Minas Gerais e as novas abordagens para uma história do império ultramarino português. Belo Horizonte: Editora UFMG, 2001.

$\overline{\text { Letras, } 2003 .}$

. Chica da Silva e o contratador dos diamantes. São Paulo: Companhia das

. O Distrito dos Diamantes: uma terra de estrelas. In: RESENDE, Maria Efigênia Lage de; VILLALTA, Luiz Carlos (Orgs.). História de Minas Gerais. Belo Horizonte: Autêntica, 2007. Vol. 1. p. 303-320.

GUIMARÃES, Carlos Magno. Escravidão e quilombos nas Minas Gerais do século XVIII. In: RESENDE, Maria Efigênia Lage de; VILLALTA, Luiz Carlos (Orgs.). História de Minas Gerais. Belo Horizonte: Autêntica, 2007. Vol. 1. p. 439-454.

HESPANHA, António M. (Org.) Nova história militar de Portugal. Séculos XVI-XVII. Vol. II. Lisboa: Círculo de Leitores, 2003.

JESUS, Nauk Maria de. Para uma história da organização militar na capitania de Mato Grosso. In: POSSAMAI, Paulo (Org.). Conquistar e defender: Portugal, Países Baixos e Brasil. Estudos de história militar na Idade Moderna. São Leopoldo: Oikos, 2012. p. 313-325. 
KARASCH, Mary C. A vida dos escravos no Rio de Janeiro (1808-1850). São Paulo: Cia. das Letras, 2000.

. The Periphery of the periphery? Vila Boa de Goiás, 1780-183. In: DANIELS, Christine; KENNEDY, Michael V. (Orgs.). Negotiated Empires: Centers and Peripheries in the Americas, 1500-1820. New York \& London: Routledge, 2003. p. 143-169.

LARA, Sílvia Hunold. Fragmentos setecentistas - escravidão, cultura e poder na América portuguesa. 2004. Tese (Livre-Docência) - Universidade Estadual de Caminas (Unicamp), Campinas, 2004.

Conectando historiografias: a escravidão africana e o Antigo Regime na América. In: FERLINI, Vera L.; BICALHO, Maria F. (Orgs.). Modos de governar. São Paulo: Alameda, 2005. p. 21-44.

MARTA, Michel Mendes. Em busca de honras, isenções e liberdades: as milícias de homens pretos forros na cidade do Rio de Janeiro (meados do século XVIII e início do XIX). 2013. Dissertação (Mestrado em História) - Universidade Federal Fluminense (UFF), Niterói, 2013.

MATTOS, Hebe. Henrique Dias: expansão e limites da justiça distributiva no Império Português. In: VAINFAS, Ronaldo; SANTOS, Georgina; NEVES, Guilherme Pereira das (Orgs.). Retratos do Império. Niterói: EdUFF, 2006. p. 29-45.

MELLO, Evaldo Cabral de. A fronda dos mazombos: nobres contra mascates, Pernambuco, 1666-1715. São Paulo: Ed. 34, 2003.

MORAES, Fernanda Borges de. De arraiais, vilas e caminhos: a rede urbana das Minas coloniais. In: RESENDE, Maria Efigênia Lage de; VILLALTA, Luiz Carlos (Orgs.). História de Minas Gerais Belo Horizonte: Autêntica, 2007. Vol. 1. p. 55-85.

MOREIRA, Luiz Guilherme S.; LOUREIRO, Marcello José G. A nova história militar e a América portuguesa: balanço historiográfico. In: POSSAMAI, Paulo (Org.). Conquistar e defender: Portugal, Países Baixos e Brasil. Estudos de história militar na Idade Moderna. São Leopoldo: Oikos, 2012. p. 13-31.

NAZZARI, Muriel. O desaparecimento do dote: 1600-1900. São Paulo: Cia. das Letras, 2001.

PAIVA, Eduardo França De corpo fechado: o gênero masculino, milícias e trânsito de culturas entre a África dos mandingas e as Minas Gerais da América, no início do século XVIII. In: LIBBY, Douglas Cole; FURTADO, Júnia F. (Orgs.). Trabalho livre, trabalho escravo. Brasil e Europa, séculos XVIII e XIX. São Paulo: Annablume, 2006. 113-129.

PAULA, Leandro Francisco. Negros no campo das armas: homens de cor nos corpos militares das Minas setecentistas (1709-1800). 2012. Dissertação (Mestrado em História) - Universidade Federal do Paraná, Curitiba, 2012.

REIS, Liana Maria. Minas Armadas: Escravos, armas e política de desarmamento na capitania mineira setecentista. Varia Historia, Revista de História do Departamento da UFMG, Belo Horizonte, n. 31, 2004.

RESENDE, Maria Efigênia Lage de. Itinerários e interditos na territorialização das Geraes. In: RESENDE, Maria Efigênia Lage de;VILLALTA, Luiz Carlos (Orgs.). História de Minas Gerais. Belo Horizonte: Autêntica, 2007. Vol. 1. p. 25-53.

RIBEIRO, Mônica da Silva. Trajetória familiar e ampliação jurisdicional: o governo do primeiro conde de Bobadela na América portuguesa (1733-1763). In: GUEDES, Roberto (Org.). Dinâmica imperial no antigo regime português: escravidão, governos, fronteiras, poderes, legados: séc. XVII-XIX. Rio de Janeiro: Mauad X, 2001. 83-96. 
SANTOS, Joaquim Felício dos. Memórias do Distrito Diamantino. Belo Horizonte: Itatiaia; São Paulo: Edusp, 1976.

SILVA, Kalina Vanderlei. Os Henriques nas Vilas Açucareiras do Estado do Brasil: Tropas de Homens Negros em Pernambuco, séculos XVII e XVIII, Estudos de História, v. 9, n.2, 2002.

SILVA, Luiz Geraldo. Gênese das milícias de pardos e pretos na América portuguesa: Pernambuco e Minas Gerais, séculos XVII e XVIII. Revista de História São Paulo, n. 169, p. 111-144, 2013.

. Sobre a "etnia crioula": o Terço dos Henriques e seus critérios de exclusão na América portuguesa do século XVIII. In: GONÇALVES, Andréa Lisly; CHAVES, Cláudia M. Graças; VENÂNCIO, Renato Pinto (Orgs.). Administrando Impérios: Portugal e Brasil nos séculos XVIII e XIX. Belo Horizonte: Fino Traço, 2012. p. 71-96.

Enviado em: 21 de outubro de 2015 Aceito em: 19 de janeiro de 2016

\section{Autor/Author:}

Ana PAula Pereira Costa <anappcosta@ig.com.br>

- Doutora em História Social pela Universidade Federal do Rio de Janeiro (UFRJ). Professora Adjunta na Universidade Federal dos Vales do Jequitinhonha e Mucuri (UFVJM), Campus de Diamantina. Desenvolve suas pesquisas com temas sobre escravidão, história militar e história das elites no Brasil colonial. É autora de Corpos de Ordenanças e Chefias Militares em Minas Colonial: Vila Rica, 1735-1777 (FGV, 2014).

- PhD in Social History from the Universidade Federal do Rio de Janeiro (UFRJ). Associate Professor at the Universidade Federal dos Vales do Jequitinhonha e Mucuri (UFVJM), Campus de Diamantina. Her researches are concentrated on themes such like slavery, military history and history of the elites in the colonial Brazil. She is the author of Corpos de Ordenanças e Chefias Militares em Minas Colonial: Vila Rica, 1735-1777 (FGV, 2014). 